\title{
LUNAR PERIODS AND THE QUEST FOR REBIRTH IN THE MAYAN HIEROGLYPHIC INSCRIPTIONS
}

Dieter Dürting

Max Planck-Institut für Entwicklungsbiologie, Tübingen

The decipherment of the hieroglyphic script of the classic Maya society is hampered by our almost complete ignorance of their mythological-religious beliefs, of their thoughts on the after-life, on the underworld journey and fate of the deceased. Most of the inscriptions are based on a frame of historical (sometimes mythical) dates, usually life-cycle and period-ending dates (Proskouriakoff 1960). In the present paper and two companion ones (Dütting 1984 and n.d.) I explored whether accession dates of Maya lords and dates of other historical events were linked with similar dates of the past, with important dates in the life of parents and forefathers, by full multiples of time-periods with astronomical significance. It turned out that the Moon and the planet Venus played a particular role in the timing of such events. The corresponding deites are the divinities most deeply involved in the resurrection process, aspects of which are discussed.

\section{Lunar periods determine distance between historical dates.}

The first part of this paper is concerned mainly with one text from Palenque, the inscription of the so-called Table of the Slaves (Ruz 1952). The 11 Calendar Round dates of this text were placed securely in the Long Count by Berlin (1965:341).

The tablet treats events in the life of lords Chaacal III and Chac Zutz' who succeeded each other on the throne of Palenque (see 
Schele 1978:64 for a brief rendering of text and iconography). Iconographycally the tablet present Chac Zutz' seated on a cushion supported by two crouched human figures, probably not "slaves" but persons attired for the bloodletting rite (Benson 1976: 50). Chac Zutz' receives the royal insignia at his accession ceremony from a male and a female attendant, probably his parents. His name glyph T109:756a is never accompanied by one of the Paler. que emblem glyphs, and he may have been a half-brother Chaacal's, not legitimized to become a ruler of Palenque. We do not know what event terminated Chaacal's short time in office $\left(532^{4}\right)$, and whether Chac Zutz' took the royal insignia by force.

The inscription starts with a reference to the preceding dynastic sequence in an unusual strongly abbreviated style ${ }^{2}$ (Fig. 1):

Al 5 Lamat $1 \mathrm{Mol}(9.9 .2 .4 .8)$, 615-Jul-26 (moon age 24-25 ${ }^{\mathrm{A}}$ )

Bla 168?:head.?:544?:116

B1b 74:184:624[583], Lord Pacal

I2a III:87:683b, ox-te.kal, "three scores"

A2b 13:644b:528P.116, "of Tun seatings"

B2 $59[683] ? .11: 644[528.116]-762$, "the scores of Tun seatings (until the seating) Chan-Bahlum's"

' Hieroglyphs were transcribed with Thompson's (1962) code numbers. The interpretation of glyphic texts (mainly based on the vocabulary of classical Yucatec, the phonemes of which were used) is founded on the assumption that the script is a mixed system of logograms or word signs (main component) and of a restricted number of logo - syllabic signs (minor phonetic component of later development), and that some graphemes aro bi- or polyvalent, having both morphemic/logographic and phonetic values, the latter either derived from or independent of the former (Dütting $1980 \mathrm{a}$ ). Examples of polyvalent signs are T528 (morphemic haab/tun, phonetic cu), T501 (morphemic nab/ha'?, phonetic ba), T585a (morphemic $b i x / p i x$ ?, phonetic be), T669a,b (morphemic kab/kam?, phonetic ka). The divergence in interpretations between different research groups is triggered to a considerable degree by different readings of the major syntactic affixes (like T23 - na or $a l, \mathrm{~T} 130$ - aan or wa), and a different attitude towards substitutions of glyphic elements, which could be based on purely phonetic or on semantic principles (graphemes that replace each other could have the same phonetic value, could correspond to the same morpheme/word with sometimes multiple meanings, or could have different phonetic values, correspond to different morphemes/ words with at least one identical meaning).

Long Count (LC) dates were converted into Julian dates with Thompson's (1935) 584,285 correlation (see Dütting 1984 for its latest, verification) and with the tables of Schram (1908). Moon ages were derived from the tables of Goldstine (1973), Venus positions were calculated by means of the data given in Tuckerman's (1964) tables.

For helpful discussions of astronomical matters I am grateful to Matthias Schramm. 
A3a I:87:683b, hun-te.kal, "one score"

- 11:644[528.116], "of Tun seatings"

A3b 684b[281]:142, "(until the seating) Kan-Xul's"

B3 XI: $89: 528$ - II $: 28: 548126,2.11 .(12.5)$

A4a $740: 246$, poc.mayih?, "(since) was washed at birth the gift"?

A4b 69:756a, title of Chac Zutz', (on)

B4 7 Caban 15 Kayab (9.11.18.9.17), 671-Jan-22 (moon age $6^{\prime \prime}$ )

A5 679a.60[121]:713a? - 89:757, forward to the accession of

B5 115?:741v:142 - 238:244:522, titles of Chaacal III, (on)

C1 9 Ik 5 Kayab (9.14.10.4.2), 721-Dec-30 (moon age $7^{d}$ ).

Glyphs A2, B2 most likely refer to the three Katun endings 9.10.0.0.0, 9.11.0.0.0 and 9.12.0.0.0 between the accession Pacal's on 9.9.2.4.8 and the accession Chan-Bahlum's on 9.12.11.12.10, glyphs A3 to the Katun ending 9.13.0.0.0 between 9.12 .11 .12 .10 and the accession Kan-Xul's on 9.13.10.6.8 (Schele 1982a:84). These statements clearly attribute to the "moon" grapheme T683b (primary value $u h$; "moon", derived value $a h$ ) an additional value kal, "score; enclose", regardless of T683a, kal, "twenty", which in the Lunar Count glyph series is never replaced by T683b. Whereas T683a stands only for kal, "twenty", T683b and its affix form T181 are polyvalent graphemes with values $u h, a h$ and $k a l$ (Dütting 1979:39; 1980a).

The text continues with an abbreviated distance number (DN) of 2 Katuns 11 Tuns (should be supplemented to 2.11.12.5) which links the birth of Chac Zutz' on 9.11.18.9.17 with the accession of Chaacal III on 9.14.10.4.2. The DN 2.11.12.5 $=18,605^{\mathrm{d}}$ corresponds to 630 lunations $\left(18604^{\mathrm{d}} .27\right)$ and to 681 sidereal lunar months or 227 triple sidereal months $\left(18606^{4} .05\right),{ }^{2}$ implying nearly identical moon ages and comparable lunar mansions ${ }^{2}$ of the two dates. The number $2.11 .0 .0=18,360^{4}$ would be an even better measure of sidereal months, since it corresponds precisely to 224 triple sidereal months (18360 .15$)$. This number would link 9.11.18.9.17 with an implied date (9.14.9.9.17) 11 Caban 0 Zec, 721-Apr-29 (moon age

$=$ One lunation $-294.53059,1$ sidereal lunar month $=27 \mathrm{~d} .32166,1$ tropical year $365^{\mathrm{d}} .2422$.

a Every triple sidereal lunar month of $81^{4} .96498$, roughly $82^{d}$, the Moon assumes about the same position along the ecliptic arc at the same time of the night (independent of its visibility which depends on the current age and phase). Evidence for the knowledge of the sidereal and triple sidereal lunar month at Palenque during the reign Pacal's and his sons is given in Dütting (1984).

On 9.11.18.9.17, 671-jan-22, ca. 19h local time, the Moon was approxjmately in longitude $30^{\circ}$, at the border Aries-Taurus. 
$28^{\mathrm{d}}$, last day of visibility), from which an implied DN $12.5=245^{\mathrm{d}}$ $=9$ sidereal months $\left(245^{\mathrm{d}} .89\right)$ would lead to 9.14 .10 .4 .2 . It is unknown why the accession of Chaacal III was timed a full multiple of lunations and sidereal lunar months after the birth of Chac Zutz' on 9.11.18.9.17, a date separated by $1.18 .9 .17=13,877^{d}=38$ tropical years $(13879.20)$ from the important half-Baktun ending 9.10.0.0.0, 1 Ahau 8 Kayab.

At his birth Chac Zutz' is addressed by the glyph 69:756a which substitutes the three down-balls of T69 for the usual T109, chac, "red, great", of his name glyph. This does not mean that T69 is another grapheme for the value chac, rather it may entitle the "bat" as a "sacrificer". I remind at the Aztec custom of pasting eagledowns (T69?) upon the hair of sacrificial victims (Sahagún, Florentine Codex, Book 2, chapt. 29). At Chich'en Itza (Temple Four Lintels, Lintel I, G4) the glyph $145 v .565$ c: 69 replaces the more frequent 145v.565c:136, suggesting a replacement T136 (may?, "gift, offering; tobacco")/ T69.

Of the accession clause A5 the first part $60[121]: 713 \mathrm{a}$ probably announces the lord's "taking/supporting $(713 \mathrm{a}=$ lat?) the bundle of rulership (60[121])", the second part 89:757 the lord's, "the first one's $(757=b a h)$ being seated on a dais or bench $(89=t u l$ or tem)".

The text continues with events in the life of Chac Zut', first with his accession on 9.14.11.12.14, a day close to the Summer Solstice (Jun 18), 19,137d, about 648 lunations (19135 d.82) after his birthday 9.11.18.9.17, and $532^{\mathrm{d}}=18$ lunations $\left(531^{\mathrm{d}} .55\right)$ after Chaacal's accession on 9.14.10.4.2. Chaacal's time in office thus was restricted to the short time of 18 lunations. The subject of the following text are war-like acts conducted by Chac Zutz' Dated 9.14.13.11.2 and 9.14.17.12.19, and the prior making of a captive on 9.14 .11 .17 .6 :

D1 8 Ix 7 Yaxkin (9.14.11.12.14), 723-Jun-15 (moon age $8^{4}$ )

C2 122:60[121]:713a - 89:757, "the fiery one (122) took the bundle of rulership - seated was the first one"

D2a 109:756a, Chac Zutz'

1 McLeod (n.d.: 102) claims a Proto-Cholan root *tul, "sit". Note Chorti (Wisdom): turuh $=$ be, be in a place, sitting; turan/turwan $=$ sit down. Note furthermore Proto-Chol (Kaufman and Norman) *tem = banco, asiento. T713a I understand as bivalent grapheme with values lah (all; end, finish; slap with the open hand) and lat' (support, hold) (Dütting $1979: 26$ ). 
D2b 168a:757, ahau?.bah, "the lord of the first ones", or "the first ruler/lord"

C3 $7 \mathrm{Ik} 5 \mathrm{Zec}(9.14 .13 .11 .2)$, 725-May-3 (moon age $17^{\mathrm{d}}$ )

D3a 25-190:544.116:178?, bat.cah?.kin.(n).al?, "fighting fervently"?

D3b 11:526:246, u.cab.mayih?, "his gift to the land"

E1a 109:756a, Chac Zutz'

E1b 126:168a:563a:122, ah.ahau?.(zi').kak, "he the lord/owner of the fire"

F1 9 Cimi 19 Zac $(9.14 .11 .17 .6)$, 723-Sep-15 (moon age 12d)

E2a 87.512[528].181:25, "making a captive"

E2b V:12:60b:671, name of captive

F2a 12:168:534:130, ah.ahau?.la.(wa), "he the lord, the named esteemed one"

F2b $12: 561 ? .598: 23$

E3 2 Cauac 2 Xul (9.14.17.12.19), 729-May-19 (moon age $17^{4}$ )

F3a 25-190:110:126?, bat.cah.chac-ah?, "fighting fervently"?

F3b 11:526:246, u.cab.mayih?, "his gift to the land"

F4a 109:756a, Chac 'Zutz'

As first noted by Berlin $(1965: 341)$, the dates 9.14 .13 .11 .2 and 9.14 .17 .12 .19 are separated by $1477^{\mathrm{d}}=50$ lunations $\left(1476^{\mathrm{d}} .53\right)$. The event glyphs D3a and F3a consist of a common constituent 190-25, bat.cah, "fighting (the doing)", and a second constituent that probably refers to "heat", 544.116:178, kin.(n).al?, in the first glyph, 110:126?, chac-ah? in the second. In contrast to $\mathrm{T} 109$, shac, affix $\mathrm{T} 110$ probably is polyvalent for the values chic/chec/chac, with principal meaning "become visible, appear" (Dütting 1984). ${ }^{5}$ For 110:126? in glyph F3a I rely on Mopan (Ulrich, de Ulrich) chücüj $=$ caliente, calor; chüc $=$ rojo, and on Yucatec (Motul) chacau - cosa caliente, calentura, calor; chïic $=1$ ) rojo, 2) cocer en agua. For 544.116:178 note Yucatec (Motul) kinal = el calor de alguna cosa, cosa caliente. An alternative, so less likely reading of the event glyphs D3a and F3a could be "beheading (190-25 = ch'ac.cal?) when the day dawns (544.116:178 - kin-al, 110:140? = chac-al?)", the victim's behead. ing being "the offering/sacrifice to the earth $(11: 526: 246)$ " (Dütting 1978: $35)$.

5. An occasional value chac of T110 is suggested by glyphs that substitute 'T110 for T109 (chac) (Lamb, n.d.; Dütting 1984). Examples are glyphs of the month Ceh (usual form T109:528) which are replaced on some Copan monuments (Stela 2, Altar U) by T110:528. Another example is the red Chaac of the east, who in the first picture of almanac 59, Codex Dresden $31 b-35 b$, is addressed by the glyph $765 b .110-668.103$, "it enters $(765 b-o c)$ the red $(110-$ chac $)$ Chaac $(668,103) "$. 
The last part of the inscription starts with a date 9.14.18.1.1, which coincides with the Autumnal Equinox in the later part of the rainy season. This date lies $1599^{4}=4 \times 399^{4}+3^{\text {d }}, 4$ synodic cycles of Jupiter, after 9.14.13.11.2. After the event glyph F5b, which resists a reasonable interpretation, the text mentions a heavenly vulture as lord of the rainy season or Tuns. ${ }^{6}$ In the text the compounds 177.507 and 181.581 could refer to the "gathering of the maize", to the approaching harvest time:

$\mathrm{F} 4 \mathrm{~b}-$ F5a $\quad 7$ Imix 4 Ceh $(9.14 .18 .1 .1$ ), 729-Sep-18 (moon age 21d)
F5b ?.513-187v:758

G1a 12.528.116:177.507:140?, "master $(12=a h)$ of the rainy season $(528.116=$ haab.kin $)$ which accumulates $(177$ $=c u b ?)$ the maize $(507: 140=$ nal. $[$ la] $) "$

G1b IV:747, ca(a)n.kuch, "heavenly vulture"

H1 VI: 758??:181.581:542, uac... - ah.mol.el

G2 109:756a - 1008[526].180, Chac Zut $z^{\prime}-\ldots$.

H2 VIII.87.329:548, 1.8.(12)

- 11:44:563b:142, i?.lem?.tzay?.om, "its account is joined with"

G3 4 Ahau 13 Yax $(9.15 .0 .0 .0), 731$-Aug-18 (moon age $12^{\text {d) }}$ $\mathrm{H} 3 \mathrm{a} 528.116: 644 \mathrm{~b}$, "seating of Tuns"

"On the West Tablet of the Inseriptions Temple, Palenque, the "vulture" is referred to in the passage (N11-P2) as part of a deity triad that precedes the name glyph of Lord Pacal: III.597a:59.43, (triad introducing glyph) / ?.120:?.1030b, God GII? / 747b, (ti) vulture / 281:23.58[509]. 229.528 , "precious liquid $(281.23=k a n \cdot[\mathrm{na}]$ or kan. $y a l)$, end $(509)$ of the [sun's] resplendence $(58=z a c)$, it begins $(229=a c)$ the [falling of] rain $(528=\text { haab })^{\prime \prime} /$ IX.765a:87, Bolon Yoc-te / 74.184.122?:624[583], Lord Pacal / 38,168a:570:140.130, (Palenque emblem).

The first picture of almanac $61, C$. Dresden $38 b-41 b$, shows an anthropomorphic vulture standing in rain falling from a sky band. Accompanying text: $326[544]$ - 326[682], "darkening of sun and moon"? / 59.501:136?, ti.ha'.may?, "place where water is the gift"? / 747b, (ti) vulture. The "wings" of T326 are of the color sequence white-black, possibly indicating a "darkening", in contrast to the black-white sequence which could indicate a "getting light". Most of the examples in the Eclipse Table of the C. Dresden are of the first type.

? T1008[526] could be a head variant of $\mathrm{T} 630$, as suggested by the variant name glyph $181.1008[526]: 130-561: 23,1030 \mathrm{~b}$ of Tikal Ruler A (usual form 181.630:130) on Bones $M T-51: A / B$ and $M T-38: A / B$ from Burial 116, Tikal Temple 1. I interpret T630 as zih, "be born, originate; birth" (Yuc/Kekchi) (Dütting 1984), and the name glyph 181.630:130 of Ruler A as ah.zih-an, "he of (noble) descent" (Yuc zijan = generación, linaje o descendencia de donde uno viene). 
$\mathrm{H} 3 \mathrm{~b}-$

G4a 5 Lamat 6 Uo $(9.14 .18 .9 .8), 730-\mathrm{Mar}^{-4}$ (moon age $11^{4}$ )

G4b ?:?:?: 188

$\mathrm{H} 4 \mathrm{a} 60[534]: 713 \mathrm{a}: 4$, "taking $(713 \mathrm{a}=$ lat"? $)$ the bundle $(60$ $=k a x)$ of the noble ones $(534)$ in the house $(4=n a)$ of"

H4b IX:1011-542a:136, name of deity

G5a 713.165:III:28:548:142, "completion (713a $=$ lah) of 3 Katuns"

G5b-

H5a 1 Caban 15 Uo (9.14.18.9.17), 730-Mar-13 (moon age 19d) H5b 113:740:23, "the appearance $(113-23=t a-n[a])$ of the washing (at birth) $(740=p o c) "$.

A DN 1.8.(12) leads from 9.14.18.1.1 to the Katun ending 9.15.0.0.0, which in turn is separated from the mentioned "capture" event on 9.14 .11 .17 .6 by $2894^{\text {d }}$, precisely 98 lunations (2893d.998). The next date, $(9.14 .18 .9 .8) 5$ lamat $6 \mathrm{Uo}, 532^{\mathrm{d}}=18$ lunations before 9.15.0.0.0, recalls Pacal's inauguration on (9.9.2.4.8) 5 Lamat $1 \mathrm{Mol}, 41,860^{\mathrm{d}}=161$ Sacred Cycles earlier. The text closes with the 3 Katun anniversary 9.14.18.9.17 of Chac Zutz' birthdate 9.11.18.9.17.

Attached to the main inscription are two small glyph panels that probably address the male attendant to the right and the female attendant to the left of Chac Zutz', most likely his parents who offer him the insignia of rulership, a mosaic-encrusted drummajor helmet and a war-shield with the eccentric flint-god on top. Text accompanying the male-attendant (I-K) :

$59.67: 616 b ?: 23 / 74: 793 a / 758: 110$.

Text accompanying the female attendant (L1-L3) : 1000a.102:592:117 / 74:565a / 758:110.

The initial glyphs could entitle the parents of Chac Zutz'. The following glyphs could then refer to "the gift (74:565a = ma-tan?; T793a variant of T565a?)", the insignia of rulership, they offer to their "child", 758:110. The latter glyph was rendered by me (Diitting 1984) as $t z$ 'ub.chic, "the child which appeared".

The name glyph of the mother, 1000a.102:592:117, can be interpreted as "she $(1000 \mathrm{a})$ who sustains/embraces $(592=$ loch $)$ the children $(102=a l)$, the growing ones $\left(117=c h^{\prime} i h / c h^{\prime} i y\right.$ ? $) "$, or 
as "the lady (1000a) with the heavy $(102=a l)$ water-container $(592=l u c h) \ldots$. . I do not accept Thompson's (1972:92) position, who - following Gates — regarded T592 as sign for the "world directions". Rather T592 may stand for luch, "jícara" (Yuatec, Cholan languages), and for loch, "tener, sostener, abrazar" (Yucatec). A variant of T592, grapheme T593, appears on the jars or gourds from which Rain Gods pour water in the design of Quirigua Zoomorph $P$ (Thompson 1962:220). Furthermore a variant of the "captor" glyph that occurs in a glyph passage of the Forth Worth Lintel (Kimbell Art Museum) from Yaxchilan, 1.131?:592, could refer to a captive as "a bent or crooked one", with T592 = loch, "bend, flex, bow, fold" (Yucatec and Cholan languages):

$$
\begin{aligned}
\text { J1,I1 } & 145 \mathrm{v}: 188.130-561 \mathrm{a}: 23 \text {, Shield-Jaguar II } \\
\text { H1 } & 671[544]: 116 \text {, chi-kin, "west" } \\
\text { G1 } & 1.131 ?: 592 \text {, "his ... bent/crooked one"? } \\
\text { F1 } & 150-122: 744 \mathrm{~b}, \text { Tah Moo (name of captive) } \\
\text { E1,D1 } & 32.168 \mathrm{~b}: 562-32.168 \mathrm{a}: 511 \mathrm{v} \text {, (Yaxchilan emblem glyphs). }
\end{aligned}
$$

Possibly Chac Zutz' and Chaacal III were half-brothers, having the same mother, but only Chaacal III having the legitimate father for becoming ruler of Palenque. On the Temple XVIII Jambs, $\mathrm{Pa}$ lenque (D3-C12), Chaacal's accession on (9.14.10.4.2) $9 \mathrm{Ik} 5$ Kayab (implied) is linked by a DN 7.14.9.12.0 $=1,112,280^{4}=4278 \mathrm{x}$ $260^{4}=1426 \times 780^{4}$ with the mythical accession date 2.0.0.10.2) 9 Ik 0 Zac of Pacal's ancestress Lady-Beast-with-Upturned-Snout, $86: 69$ ?: $610: 23-1000 \mathrm{~b}-343: 793 \mathrm{~b}$. The ancestress herself is connected in D11-C13 by the glyph $17.565 \mathrm{a}: 88^{8}$ with a lady entitled I.1000b. 102:592:130, "unique lady (I.1000b) who sustains/embraces $(592=l o c h)$ the children $(102=a l)$ who came into existence $(130=\text { yan? })^{\prime}$, the same as the supposed mother of Chac Zutz' mentioned on the Slave Tablet.

The initial date of the Temple XVIII Jambs records the birthday of Chaacal III, including its 819-day cout augury. Chaacal is

8 This is the so-called "relationship" glyph which could denote "the great $(17=n o h ?)$ meeting $(565 \mathrm{a}-t a h)$ passed by $(88)$ ", or "the meeting (565a) of the great ones (17) passed by (88)". Note Chol/Chorti/Tzeltal taj-, "find, meet", with respect to main sign T565a. Suffix T88 could be the Yucatecan man-, or the Cholan num-, "pass by". The T17 superfix is replaced more frequently by T18 ( = T88[17]), the suffix T88 sometimes by T136 (may?). MacLeod (n.d.) interpreted the T88 suffix as verbal ending $-a n$, a reading attributed by me to $\mathrm{T} 130$ (besides $w a$ ) and to T23 (besides $n a$ ). 
bearing his pre-accession title $758: 110-741 \mathrm{v}$. After the birth clause the father Chaacal's is addressed;

A1-

A13 9.12.6.5.8, 3 Lamat 6 Zac, 678-Sep-13 (moon age 21 ${ }^{4}$ )

A6-B8 G9/F; 19D, 5C, X5, B, 10A (lunar count)

B12 1.10.1, DN / 1 Manik 10 Pop (9.12.4.13.7) / glyphs of A9-

B12 1.10.1, DN / 1 Manik 10 Pop (9.12.4.13.7) / glyphs of 819-day count

B13a 740:126, poc.ih, "washing (at birth) the descendant/grandchild"

B13b 758:110, tz'ub.chic?, "the child which appeared"?

A14a 741v, Iguana (title of Chaacal)

A14b 1:533:24, u.ahau.(l)il, "his lordship/reign"

- B14-

A15 231[1008] - 561a:23 - 793a, (father of Chaacal).

The name glyph of Chaacal's father, a monkey head(?) with attached sky-sign and bird-head 793a, the latter a variant of T565a (ta/tah/tan?), differs from the likely name glyph of Chac Zutz' father, given on the Slave-Tablet. According to the inscriptions on a limestone flanged incensario stand from the Temple of the Cross (Bodega No. 478; Schele and Mathews 1979:281), H7-H9, Chaacal's father T231[1008] died on (9.12.8.10.0) 9 Ahau 8 Muan, and one could ask whether he was a younger brother Pacal's, the latter being still alive at this time."

The distance between Chacal's birthday 9.12.6.5.8 and Chac Zutz' accession date 9.14 .11 .12 .14 is $2.5 .7 .6=16,346^{\mathrm{d}}=28$ synodic cycles of Venus (16349 .2$), 28 \times 584^{4}-6^{4}$, and about 41 synodic cycles of Jupiter (16354.9). Venus was Evening Star on both dates, $143^{d}$ before Inf. Conj. of 679-Feb-3 on 678-Sep-13 (9.12.6.5.8), and $144^{\text {d }}$ before Inf. Conj. of 723-Nov-6 on 723-Jun-15 (9.14.11.12.14).

Remarkable astronomical distances were thus found to link Chac Zutz' birthday and Chaacal's accession date, and Chaacal's birthday and Chac Zutz' accession date. This suggests an intimate relation-

- Among the Temple XVIII stucco glyphs we find the name glyph of Chaacal III (Schele and Mathews 1979: Nos.434,518), 1010[74].229:528:534 and 1010b[74].743[528]:534, of Chaacal's and Chac Zutz' mother (op cit.: No. 459), 1000a.102:592:117, and of Chaacal's father (op. cit.: Nos.406, $456,461,515,517), 231 . I V / 561 \mathrm{a}: 74 / 502: 565 \mathrm{a}$. None of the Temple XVIII glyphs refers to Chac Zutz'. 
ship between the two lords which is expressed also on the fragmentary tablets of the Orator, presenting Chaacal III, and Scribe, presenting Chac Zutz', both engaged in bloodletting rites. ${ }^{10}$ These tablets were paired, the Scribe being the right alfarda, the Orator the left alfarda of the south stairway of the Tower in the Southwest Court of the Palace (Schele and Mathews 1979: Nos. 141, 142; Schele 1982a:88).

Chaacal's birthday 9.12.6.5.8 is linked furthermore with the date 9.14.18.1 of the Slave-Tablet by $2.11 .13 .13=18,633^{\mathrm{d}}=682$ sidereal lunar months $\left(18633^{d} .37\right)=631$ lunations $\left(18633^{\mathrm{d}} .80\right)$, about 51 tropical years $\left(18627^{4} .35\right)$, implying comparable lunar mansions, moon ages and solar positions

It should be mentioned finally, that the 819-day count date (9.12. 4.13.7) 1 Manik 10 Pop, 677-Mar-1 (moon age $21^{d}$ ), precedes Chaacal's birthday 9.12 .6 .5 .8 by $561^{d}$, precisely 19 lunations $\left(561^{\triangleleft} .08\right)$, and the Katun ending 9.13.0.0.0 (the 89th tropical year anniversary of Pacal's birthday 9.8.9.13.0) by $5493^{\mathrm{d}}=186$ lunations $\left(5492^{\mathrm{d}} 69\right)$.

The genealogical record of ancestors of the royal house of $\mathrm{Pa}$ lenque on the Tablet of the Cross includes two earlier lords named T229:528:178, Chaacal I and Chaacal II. The birthdate (9.4.9.0.4.) $7 \mathrm{Kan} 17 \mathrm{Mol}$ of Chaacal II precedes the accession of Chaacal III, 9.14.10.4.2., by $72,438^{d}=2453$ lunations $\left(72438^{d} .54\right)$, and the accession of Chac Zutz', 9.14.11.12.14, by $72,970^{d}=2471$ lunations (72970 .09$)$. The accession of Chaacal II on (9.6.11.5.1) 1 Imix $4 \mathrm{Zip}$, on the other hand, precedes the accession of Chaacal III, 9.14 .10 .4 .2 , by $57,221^{d}=98$ synodic cycles of Venus $\left(57224^{d} \cdot 16\right)$. The distance 2.2.4.17 $=15,217^{\mathrm{d}}$ between birth and accession dates of Chaacal II almost equals 557 sidereal lunar months (15218d.16).

Among the ancestors listed on the Cross-Tablet are also an earlier Kan-Xul I, accession (9.4.14.10.4) 5 Kan 78 Kayab, $63,284^{4}=$ 2143 lunations $\left(63284^{4} .05\right)$ prior to $(9.13 .10 .6 .8) 5$ Lamat 6 Xul, the accession of Kan-Xul II (the younger son Pacal's), and an earlier Chan-Bahlum I, accession (9.6.18.5.12) $10 \mathrm{~Eb} 0$ Uo, 40,818 $=1494$ sidereal lunar months or 498 triple sidereal months (40818.56) prior to $(9.12 .11 .12 .10) 8$ Oc 3 Kayab, the accession of Chan-Bahlum II (the elder son Pacal's).

As shown previously (Dütting 1984), the accession of Kan-Xul II on 9.13 .10 .6 .8 was furthermore linked by $31,720^{\mathrm{d}}=387$ triple si-

10 Reference to bloodletting, to "the piercing of the tongue (712:81 = ak.kik?)", is made on the Orator in B1, 229:712:81?.229:504:24, and on the Scribe in C1, 229.712[504]:24. See also Benson (1976:50). 
dereal months $\left(31720^{4} .45\right)$ with Pacal's accession on 9.9.2.4.8, which in turn was connected with Pacal's birthday 9.8.9.13.0 (a first appearance of Venus Evening Star after Superior Conjunction) by $4508^{\mathrm{d}}$ $=55$ triple sidereal months $\left(4508^{\mathrm{d}} .07\right)$, all these dates implying comparable lunar mansions (the Moon, of different age and phase, was on these dates in the third station Turtle Stars of the supposed 13 constellation zodiac of the Maya).

The latest carved tablet from Palenque, the Tabiet of the 96 Glyphs (probably from a niche in the lower step of the Tower south stairs) first refers to Pacal (dates 9.11.0.0.0 and 9.11.2.1.11), and then lists the accession dates of Lords Kan-Xul II (9.13.10.6.8), Chaacal III (9.14.10.4.2) and Kuk (9.16.13.0.7). Chan-Bahlum II and Chac ' 'utz' are not included in this sequence, as if these lords did not belong in the direct line of Pacal's descendants. The ununsual status of Chac Zutz' (and of Chan-Bahlum?) is supported by this passing over in silence. The second date of the tablet (9.11.2.1.11) 9 Chuen $9 \mathrm{Mac}$, is connected with Pacal's accession on 9.9 .2 .4 .8 by $14,343^{\mathrm{d}}$ $=175$ triple sidereal months $\left(14343^{\circ} .87\right)$, and by the DN 2.8.4.17 $=17,377^{d}=212$ triple sidereal months $\left(17376^{d} .58\right)$ with the accession of Kan-Xul II on 9.13.10.6.8 (Dütting 1984).

To summarize the first part, the accession dates of Palenque lords are frequently linked by full numbers of lunations or sidereal lunar months with important birth and accession dates of the past, implying identical lunar phases (moon ages) or lunar mansions (positions of the moon with respect to prominent starts of the ecliptic).

\section{Lunar Periods recorded on Itzan Stela 17 and the Kansas Lintel}

Distances that equal full multiples of sidereal months are not only found in texts from Palenque, but also in the inscriptions of other sites (Dütting 1984 and n.d.). To give an example from the Río Pasión area of the central Petén, the large, partly destroyed inscription of Itzan Stela 17 (unpublished drawing by Ian Graham) is grouped around 12 historical dates (not all of them recoverable), three of them being linked by full multiples of sidereal months implying comparable lunar mansions.

Date A (A1-B8), the initial birthdate 9.15.4.15.3, 5 Akbal 11 Xul, 736-May-26 (moon age $11^{d}$ ), precedes date I (I1-J2), (9.17.7.6.3) [4] Akbal 1 Zec, 778-Apr-16 (moon age 15 ${ }^{d}$ ), by $2.2 .9 .0=15,300^{d}$ $=560$ sidereal months $\left(15300^{4} .13\right)$, and the somewhat doubtful date 
G (H2-G3), (9.16.4.6.5)? 7 Chicchan 18 Yax(?), 755-Aug-17 (moon age $5^{d}$ ), by 19.9.2 $=7022^{d}=257$ sidereal months $\left(7021^{d} .67\right)$. Date A is linked furthermore with date H (H9-G10), (9.16.17.4.18) 6 (Etz'nab) 6 Xul, 768-May-13 (moon age $22^{d}$ ), by $1.12 .7 .15=$ $11,675^{d}=4 \times 2920^{4}-5^{4}$, about 4 Octaeteris cycles $\left(11680^{4}=\right.$ $\left.32 \times 365^{d} 20 \times 584^{d}\right)$. Venus was Evening Star on both dates, on dates A $84^{4}$ before Inf. Conj. of 736-Aug-18, on date $\mathrm{H} 88^{4}$ before Inf. Conj. of 768-Aug-9.

Date $\mathrm{A}$ is separated from the Katun ending 9.15 .0 .0 .0 by $1743^{\mathrm{d}}=$ 59 lunations $\left(1742^{d} .31\right.$ ), from 9.15 .10 .0 .0 by $1857^{d}=68$ sidereal months (1857 .87$)$. The distance between date $A$ and the IS date of Dos Pilas Stela 16/ (Aguateca Stela 2), 9.15.4.6.4, 8 Kan 17 Muan, 735-Now-29 (moon. age 10 $10^{4}$ ), is $179^{4}$, about 6 lunations $\left(177^{d} .184\right)$. The Lunar Series glyphs of IS dates counted besides the actual moon ages of the dates (glyphs D/E) also the number of completed lunations within a cycle of six (glyph $\mathrm{C}$, running $\mathrm{OC}$ $=1 \mathrm{C}, 2 \mathrm{C}, 3 \mathrm{C}, 4 \mathrm{C}, 5 \mathrm{C}, 6 \mathrm{C}, \mathrm{OC}=1 \mathrm{C}$ ) interrupted occasionally by sequence of 5 lunations in anticipation of the later, more refined lunar eclipse warning table of Codex Dresden 5I-58. The Lunar Series of the IS dates 9.15.4.6.4. (Dos Pilas St. 16), 10D (moon age $10^{4}$ ) $--O C-X-10 \mathrm{~A}$, and 9.15 .4 .15 .3 (Itzan St. 17), 13D - OC $-\mathrm{X}-10 \mathrm{~A}$, being separated by 6 completed lunations, thus record the same moon number OC (T4.1000a:713a.181). The date 9.15.4.6.4 in turn is separated by 4.6.4. $=1564^{\mathrm{d}}=8 \times 6$ lunations $+1 \times 5$ lunations from 9.15.0.0.0, the $\mathrm{C}$ number of which is also given as OC (Piedras Negras St. 11). The prefix T4 (na) of the OG glyph my refer to the Moon Goddess as being in her "house".

Date A of Itzan St. 17 is unusual for having inserted the glyphs 59.bird's head:? / 1.122:563aP, u.kak.( $z^{3}$ ), "his fire" / 109?skull.(name/title of deity), between the glyphs of the lunar count and the day 5 Akbal 11 Xul reached by the IS.

A comparison of the unusual distance number introducing glyph 1 or 13.664:1 of Itzan St. 17 (G13,I12,L10) with the standard DNIG 1.573:12 suggests a substitution T573, hel/kex, "change"/T664, hal, "change" (Quichean languages only). For T664 - hal see Dütting (1978:32, note 23). The substitution of the suffixes $\mathrm{T} 12 / \mathrm{T} 1(u)$ is not easily explained. I am inclined to interpret $\mathrm{T} 1.573: 12$ as "its (1) change (573) comes to an end (12)", with T12 being bivalent for the agentive particle ah and for a term denoting "end, finish", perhaps related to the Chol term ujtel, "terminarse" (one could consider also the Yucatec $x u l$, "end", as one value of T12; Dütting 1978:43). 
The text of Itzan Stela 17 begins with the birthdate of a lord (date A, birth glyph 740:126.181 in A9) who acceded to the throne at the age of 12 years, 171 days on (9.15.17.8.17) ? 9 Caban 5(?) Muan date (F, F11-E12), 748-Nov-13 (moon age 19d). The accession clause (F12-F13) reads: 617a:713a:683b, (h)il-lah-ah/kal, "all (lah) see (il) the noble/true (hah) or enclosed (kal) one"? / $59: 110: 758$ ?:?, "at the place (59) where appears/appeared (110 $=$ chic/chec/chac ..." / 74:561c:23.deity head?, "heavenly master ..." (name/title of seated lord) / 168a:686a[501]:87, ahau... ba-te, "lord/ruler of Itzan". The following date G (9.16.4.6.5)? probably is the death-date of the mentioned lord (death 11?:77[575]. $765 \mathrm{a}: 130 / 58[533] ? .16$ ? :503:82? in H3/G4 preceding the lord's name clause), but the meaning of dates $H(9.16 .17 .4 .18)$ and $I$ (9.17.7.6.3) remains unclear. A full multiple of sideral months between the birth and death date of a lord certainly is accidental, but this must not be the case for the precisely 560 sidereal months between dates $A$ and $I$. The full moon date I, 778-Apr-16, does not coincide with a lunar eclipse (Oppolzer 1887-355).

An early-classic Full Moon date is recorded on a Lintel in the collection of the Nelson-Atkins Museum of Art, Kansas City (Mayer 1980: Plates 39/40). The text (read from right to left) starts with an IS date and its Lunar Count glyphs (C1-B3a).

9.3.19.3.8, 7 Lamat / V.617a:670 (G5) / 128:60a:23 (F) / 679a. 602v:139 - 122.120[202:24].291 / XVI.45.713b.181:125 (16D) / IV.173.181:713a (4C) / 683a.X (A10) / 173:33.1016.118v (X2) / 11 Kankin.

The IS corresponds to 513-Dec-28 (moon age $15^{\mathrm{d}}$; compare recorded moon age of $16^{\mathrm{d}}$ ), the first Full Moon after the Winter Solstice (Dec 18). The glyphs inserted between glyphs F and 16D actually could refer to the Winter Solstice, when "the fiery one (122 = kak) with the deer antler (291) (reference to underworld sun?) is turning $(120=n o c-)$ from darkness $(202)$ to light $(24, i l$, the becoming visible)". The distance of 9.3.19.3.8 to the unrecorded 9.3.10.0.0, 1 Ahau $8 \mathrm{Mac}$, 504-Dec-7 (moon age 15 ${ }^{\mathrm{d}}$ ), the date of a Jupiter-Mars conjunction (see Tuckerman 1964:270), is $3308^{d}=$ 112 lunations $\left(3307^{\mathrm{d}} .43\right)$.

In the following the text continues with a DN $14.12\left(=292^{\mathrm{d}}=\right.$ 0.5 Venus Periods) and the Katun ending (9.4.0.0.0) 13 Ahau (18 Yax), 514-Oct-16 (moon age 12d) (B3b-A5), and thereafter with non-calendaric glyphs that could refer to the feared death of a 
lady, possibly the feared loss of the Moon Goddess in a lunar eclipse, which fortunately did not occur on 9.3.19.3.8 (A6-B5): 13.1008v, zat.xib?, "fear of loss/death" / 177.234?.1040:24, cub?.chek?.cim-il, "of the descent of ... death" / 1000a.151v — ?:93v:522:60 1000a.109, (reference to lady or goddess) / torch.515.181:178, tah.chuc-la-ah, "the torch is taken by"? / 74?:1017b-?.head:125.747v: 130 , (reference to Sun God?).

\section{A Codex-style Vase of the Ik-Emblem Site}

An exquisite Codex-style vase from the unidentified Ik-emblem site of the northern Peten (Vessel 186 in Robicsek-Hales 1981, Vessel 12 in Robicsek-Hales 1982) (Fig. 2) presents a lord of this site performing the bloodletting by penis perforation in front of a seated woman, with blackened eye marking, who offers him a Spondylus shell (T607a) with attached mask of the $x o c$-fish. To the right of this scene the Hero Twins of the Popol Vuh are presented, (1) Xbalanque, the representative of the descending Venus - Evening Star and Night-Sun who upholds a large dish containing bloodletting paraphernalia, ${ }^{11}$ and (2) Hunaphu, the representative of VenusMorning Star who is reclined on a coiled serpent and has a big bundle fastened to his back. The scene is complemented by two flying birds (a black heron and a white vulture?) and to the right of Hunaphu by a heavenly symbol, the front-head of the double-headed celestial serpent or dragon, above the profile inage of an agnathic deer skull(?), perhaps symbolizing the entrance to the underworld (cf. Robicsek-Hales 1982:40).

The glyphic text along the rim begins with glyphs of the pottery standard glyph sequence (A-K) :

229.616:126 / 24?:713a.181 / ?.741a? / 758v.671 / 61.? / 1000[291].? / 683a.178 / 61?.77:585a / 59.61:? / 1000f.? / 738a.130? and continues with titles of the lord of the Ik emblem site (L-R): 168b:518a.130 / 87:513.188 / 25?.507? / 168b:526.48, ahau.cab. $x a m(a n)$, "lord of the northern land"? / 126.168b:683b, ah.ahau.uh. "he, the lord (with) the necklace" / 79?:513.184.74, (name of lord) / 38.168b:503.130, "the noble blood(-descendant) (38), the lord (168-130) of the Ik emblem (503) site".

11 It looks as if Xbalanque is hunch-backed with a small pack attached to his back. 
The two glyph panels above the seated woman (the lord's mother?) and in front of the lord most likely refer to the lord's self-castigational blood offering, ccrtainly a historical event and not a mythical one of the distant past:

$\mathrm{S} 1, \mathrm{~S} 2 \quad 13$ Oc 8 Zip $(9.18 .3 .8 .10)$

S3 ?.501[202]:12, "anointed/besmeared is $(501-12=n a b \cdot a h ?)$ with blood? (202)"

T3 I.1000v, hun.ahau?, "the unique lord"12

S4 VI.168b:518a, uac.ahau..., "emerged has the ruler of ..."

T4 513:59.126, tzic/xoc.ti.ih, "who counts toward the back"

U1 ?.524:136, u?.cab.may? "his offering to the earth"

U2 $38.168 \mathrm{~b}: 503$, "the noble blood(-descendant), the lord of the Ik emblem site".

The lord's deceased mother or an ancestral lady is invoked by the self-castigational blood-offering on a day $13 \mathrm{Oc} 8 \mathrm{Zip}$, with likely LC position 9.18.3.8.10. In the 584,285 correlation this is Julian Day $2,011,135$ corresponding to $794-$ mar-10 (moon age $4^{\mathrm{d}}$ ). On this day or the day before Venus-Evening Star disappeared for the Inf. Conj. of March 13 (ca. $5^{\mathrm{h}}$ local time). With the tables in Neugebauer: (1938:318) I estimate 3-4 days between heliacal setting of VenusEvening Star and the mentioned Inf. Conj. at a longitude of the Sun of $354^{\circ} .15$ (Mar 10, 20 local time) and the geographical coordinates of Tikal (north latitude $17^{\circ} .22$ ).

The date 9.18.3.8.10 is distinguished furthermore by lying 1.16 . $9.10=13,150^{-1}=36$ tropical years $\left(13148^{d} .72\right)$ before the Batkun ending 10.0 .0 .0 .0 , and $18 \cdot 3.8 .10=130,850^{4}=4431$ lunations $\left(130850^{d} .04\right)$ after the Baktun ending 9:0.0.0.0. In addition it is separated from the half-Baktun ending 9.10 .0 .0 .0 by $8.3 .8 .10=$ $58,850^{4}=2154$ sidereal and 718 triple sidereal months $\left(58850^{4} .85\right)$.

The other possible LC position 9.15 .10 .13 .10 of 13 Oc 8 Zip, $1 \mathrm{CR}$ earlier, would place the date on $742-\mathrm{Mar}-23$ (moon age $12^{\mathrm{d}}$ ). Venus was invisible, being $8^{4}$ before Sup. Conj. of 742-Mar-31, ca. $2^{\mathrm{b}}$ local time. In view of the aforementioned implications I regard the later LC position 9.18.3.8.10 as much more likely. As bearer of a dish with bloodletting paraphernalia Xbalanque is the divine representative of the human lord. $\mathrm{He}$ is distinguished by jaguar-skin

12 Glyph T3 could address also the seated lady, I.1000b, hun.na/ixic, "unique mother/lady". Such an interpretation would demand a different reading of glyph $\mathbf{S 3}$. 
patches on body, legs and face (around the mouth), and is entitled by the glyphs $(\mathrm{V}, \mathrm{W})$ above the dish: 177? head of Xbalanque / 33.1016[202]?. The prefix T177 (cub?/em?) of the head glyph V could indicate that Xbalanque is the one who "descends" into the underworld. Since the vessel might have been looted from the tomb of the lord of the Ik emblem site mentioned in the rim inscription, it is possible that he had died before 9.18.3.8.10, and that the depicted bloodletting was performed by his son as part of rituals necessary for invoking the lord's rebirth or resurrection. In this case the depicted woman could be the lord's deceased wife, the mother of the son.

Remarkably, Xbalanque offers the dish with bloodletting paraphernalia to the coiled serpent of rebirth with opened jaws on which his twin-brother Hunahpu is reclined. The latter is distinguished black spots on body, limbs and face, and is addressed by two glyphs in front of his face $(\mathrm{X} 1, \mathrm{X} 2): 329.533[202]$ ? / 33.1016[202]?.13

On the magnificent Vessel 117 (Robicsek-Hales 1981) Xbalanque and Hunaphu appear respectively as attendants at the western entrance to and the eastern exit from the interior of the earth, which is represented; as a turtle-carapace. They attend a reborn/ resurrected human lord who emerges from a cleft in the middle of the carapace. These three figures most likely can be identified with the gods of the Palenque triad, Xbalanque with God GIII, Hunaphu with God GI and the reborn human lord, the reborn sun-maize deity with God GII (Dütting 1984). The gates to the interior of the earth, to the underworld, are occupied on the west side of the turtle - carapace by the Pax God, on the east side by the Uinal toad.

On the Vase from the Ik emblem site the cosmic dimension is represented by the front-head of the Celestial Dragon and the deersikull assemblage, the supposed entrance to the underworld.

Inscribed on Hunahpu's bundle is the glyph T679a?.25:507, known from the bundle of Yaxchilan Lintel 1. I favor a reading nal, "corncob, ear of corn, elote", of T507, and consider corncobs/ elotes as principal content of the bundle. I doubt that the bundle contained bloodletting paraphernalia, as surmised by Merle Robert-

13 The second glyph is a title of the Hero-Twins, perhaps denoting "Hlood (- descendant) ( 33 - kik) of the hidden? (202) fathers (1016 = yum?)". The reading T1016 - yum is not entirely certain; one could consider also a reading $k u$, "divinity, divine", of this grapheme. The "blackening" of T1016, here indicated by the infixed T202, must not be related to T586/602, pa. Rather it could be associated with T95, ek, "dark, black; star". 
son (1972), since on our vase these regalia fill Xbalanque's dish. The deeper meaning of the glyph T679a.25:507 can be derived from a passage of the Middle Tablet of the Inscriptions Temple, Palenque, that follows the date $(9.11 .0 .0 .0) 12$ Ahau 8 Ceh (A2A3), 652-Oct-11, a first appearance of Venus-Evening Star, $31^{\circ}$ after Sup. Conj. of 652-Sep-10 (cf. Lounsbury 1982) (Fig. 3):

B3 1000f:116.125, ahau.kin-(t)-ah, "lords are the prophecy"

A4 24:561a:23.1000a, il.caan.(na).ix(ic)/na, "it takes care (of them) the heavenly lady/mother"

B4 249:526:178.181, "from the cleft in the earth $(249: 526=$ heb.luum) emerged (178.181)"

A5 $24.1040 \mathrm{v}: 87$, Venus-Evening Star

B5 249:526:178.181, "from the cleft in the earth emerged"?

A6 V.1021v:87, (the Zip Monster, here a title of the Evening Star?)

B6 86.116.561.116:23, "(in) the highest (86) heaven $(561: 23)$ (is)"

A7 679a.25:507, i.ca.nal = ican.(n)al, "the bearer of elotes/human offspring"? /

B7 526P:178, cab-al, "below on earth (is)"

A8 679a.25:507, "the bearer of elotes/human offspring"?

The verbal root ic-, "carry, bear", is known in particular from the Quichen languages. Kekchi (Sedat): $i k=$ carga, $i k a n c=$ cargar. Cakchiquel $($ Saenz) $:$ ikan = llevar carga, ikalem $=$ cargo, dignidad. Pocomchi (Miles 1957:756) : ikan = carrier, bearer, man of obligation. The "bearer of elotes", and metaphorically of "human offspring", seems to be the goddess addressed by glyph A4, the Moon Goddess, as suggested by a passage from the West Column of the South Building of Xcalumkin (A1-A5):

$1 ? .67: 642.24$ ? / $518 \mathrm{c}: 59-689$ (= 586v) :229 / 679d $-25: 688$ $(=507 \mathrm{v})$, "bearer of elotes/human offspring"? / $630-683 \mathrm{~b}: 178$, "the moon $(683 \mathrm{~b}=u h)$ who gives birth $(630=z i h$ ? $)$ to the offspring $(178=a l$ ? $) " / 68: 679 \mathrm{~d} .59$.

That the Moon Goddess owns the bundle is best demonstrated by a looted lintel or panel from Yaxchilan that shows the goddes, or her human representative, a deceased queen of Yaxchilan, seated in a lunar crescent, holding the bundle on her outstreched left hand (Dütting 1978a: Fig. 6).

Frequently the introductory glyph $1 / 204.60 \mathrm{~b}: 757$, Schele's (1982) "general verb", could refer to the "sacred bundle", an emblem of 
rulership, given on Yaxchilan Lintel 1 to the newly inaugurated chief, Lord Bird-Jaguar, by a lady (his wife?), the representative of the Moon Goddes.. One possible translation could be u.kax.bah, "her bundle with first things", "her bundle of the first ones". This interpretations depends on the presence of the T60 $\mathrm{b}$ superfix and on the correctness of the kax reading which was derived from the compounds T60b:528, kax.haab, "falling rain/ binding the years" (Dütting 1965:70; 1976:60, Note 8).

To declare the T757 rodent as a "rabbit", umul in the Quichean and Mamean languages (Schele and Miller 1983:23), does not account for the small ear and eye of this animal which in my opinion presents the "gopher", bah (Dütting 1976:56). The characteristics of a rabbit, large ears and eyes and split lips, are well presented in the underworld scene on a classic Maya polychrome vessel (Justin Kerr 1983, Photo No. 2026) (Fig. 4). In this scene God CH, I.1003c, probably Hun Ahau/ Hunahpu/ Venus-Morning Star, holding a bouquet of flowers, is seated on a bench, with a mirror-like object in front and a whirling crowd of 8 rabbits below. They all face a seated attendant in front of the bench, perhaps the deceased in the underworld, who presentes the gift of a large turkey (cutz) to the Venus god. A second attendant behind the divine lord offers him a little bird. The rabbits and Hunahpu are addressed in the text next to the god:

$280: 23$, "house $(23=n a)$ of the Muan? $\left(280^{-}=\right.$muan-feather $)$" / 1 ?.759?:291?, "his? (1) rabbits $\left(759=t^{\prime} u l\right)$ finish resting (291 $=x u l u b=x u l . l u b) " ? /$

$74 ? .280: 23$, "master $(74=m a h)$ of the Muan house $(280: 23)$ "? ( = God L)/

228?.604, ah?.ku, "divine one" /

$126.534: 246$, "the one $(126=a h)$ whose gift $(246=$ mayih? $)$ is the emerging/arising $(534=\text { lok/lik-? })^{\prime 14} /$

14 One could claim a hypothetical reading T126.534 - ah.la, "named/ noble one", supposedly the classic Maya language had a loan word $l a$, "name", derived from Zapotec, which now is lost. On the other hand, a morphemic value lak, "compañero, próximo, esposo, amigo", or lik-, "to arise" (Yucatec), could be reconciled like the phonetic la with the glyph T534:544.116, la.kin/la $(k) . k i n / l i(k) . k i n$, "east" of the Codices. Previously I considered a reading lok- of T534, which means "esteemed, beloved" in the Quichean "to emerge" in the Cholan languages. This reading would claim a lost term $l o(k)$. kin (emerging of the sun) for "east" in Chol. Earlier attempts to read the glyph 534:544.116 as el.kin (emerging of the sun), with T534/178 corresponding to the Quichean el-, "emerge", are doubtful. Grapheme T188 probably corresponds to the values $l e$ and $e l$. 
I.1003c, Hun Ahau/ Hunahpu (the seated lord with black spots on his body) /

151?.1?:head: 136 .

The scene is placed in the house of God L, the ruler of the underworld, who usually is presented wearing a headdress of Muan-feathers. It is still a long way towards the understanding of such underworld scenes of the lost resurrection codex. Why are there 8 rabbits (animals of the moon), and what is the meaning of the turkey (in the Mexican Tonalamatl Aubin the disguise of the Rain God Tlaloc), of the little bird and the flower bouquet? Hopefully, as more vessels are unearthed, the Maya underworld beliefs will lose some of their mystery.

IV. Do the Moon Goddess and God $N$ participate in the resurrection of a human lord?

What could have been the reason for timing historical events according to lunations and sidereal months? Was the Moon underestimated in previous studies of Maya religion? The Moon Goddess probably played a decisive role in the resurrection of a deceased lord, as suggested by the Moon's passing the triple arrangement of Mars, Jupiter and Saturn in Scorpius (close to Antares) on the important Palenque date 9.12.18.5.16, 2 Cib $14 \mathrm{Mol}, 690-\mathrm{Jul}-19 / 20$, the first day of rituals most likely devoted to the resurrection Lord Pacal's (Dü:ting 1984).

The second date of the 2 Cib 14 Mol rituals, (9.12.18.5.17) 3 Caban $15 \mathrm{Mol}$, a day under the patronage of the Moon Goddess, places emphasis on the three main levels of human descent, refers successively to the "grandfathers/ancestors" represented by the head T1014a of God N, to the "dying ruler" descending in the "west" represented by glyph $1010 \mathrm{~b} .184 .74$ or $671[544]: 116$, and to the "sprouts/descendants of the mother/lineage" represented by the glyp 744a.4 or 23, kuk.na (Foliated Cross-Tablet, M5-M7; Sun-Tablet, 07-09). The day thereafter, 9.12.18.5.18, was the 7 Tun anniversary of Pacal's death. The last day of the rituals, 9.12.18.5.19, was the day of a "fish in hand" and "bloodletting" rite, the latter performed by Pacal's elder son and successor Chan-Bahlum. In the "fish in hand" rite (event glyph T714) a deceased ancsstral lord (in the 
present case most likely Pacal) was invoked for his rebirth or resurrection (see Dütting n.d.).

The "ancestors" (Mams) are addressed also in a passage of the West Tablet of the Inscriptions Temple, Palenque, devoted to $\mathrm{Pa}$ cal's wife, Lady Ahau Hel, most likely to her marriage on a day Caban (Fig. 5):

Q3-Q4 $17 \mathrm{Kin}$ (added to) 3 Ahau 3 Uayeb (9.9.13.0.0)

R4 679a.1014a, i?.mam, "her grandfathers"

Q5 23.669b:130, na.kab-aan/kaba-an, "the house/lineage is named"? ?15

R5 1000a.168a:573, (of) Lady Ahau Hel (on)

Q6,R6 7 Caban 15 Pop (9.9.13.0.17), 626-Mar-19 (moon age 16 ${ }^{\mathrm{d}}$ ). Lady Ahau Hel probably was "seated", made the wife Pacal's and queen of Palenque on 9.9.13.0.17, as suggested by the following text that leads to the death date of the lady:

Q7-Q8 2.7.6.1, 17041 days

R8 644b:24.125, chum.il.ah?, "since she was seated"

Q9 113.V:125:757, ta.ho.ah.bah?, "at the place of the five or beloved first ones"

R9 679a.77:575, i?.xik.noh?, "until the great departure"

Q10 11:58[533].23:503:24, e/i.zac-ahau.na.ik-il, "of the fainting queen's, the mother's spirit"

R10 1000a.168a:573, Lady Ahau Hel, (on)

Q11 5 Etz'nab 6 Kankin (9.12.0.6.18).

15 I render $\mathrm{T} 669 \mathrm{a}, \mathrm{b}$ as a phonetic $k a$ and a morphemic/logographic $k a b$ (hand) or kam (to receive). T23 is either na (house, mother) (Knorozov) or ay/yal (woman's child, liquid) (Barthel), but probably not both. The na reading of T23, which Lounsbury extended to the complementary value an, makes more sense in the present context. The al reading tempted me to consider 9.9.13.0.17 erraneously as birthday of Lady Ahau Hel (Dütting 1978a:193). This is impossible, since it would make the lady 9 years old at the birth of her first son Chan-Bahlum on 9.10.2.6.6. Other affixes that may have the value $a l$ are $\mathrm{T} 102$ (polyvalent for $-V c$ and $-a l$ ?) and T178/140 (bivalent for $l a$ and al?, previously read by me as el).

Suffix T130 I understand, following Knorozov, as the Yucatecan past participle verb ending —aan/—an/ahan, which could be related to a logographic value 'ahan, "elote", of T130. In addition I accept for T130 a phonetic value wa. A verbal ending -wa does not occur in Yucatec and is very unproductive in the Cholan languages where it is found only rarely in Chorti (McLeod n.d.), this in contrast to the high frequency of the verbal suffix T130 in the glyphs. Of greater importance is the Cholan positional verb ending - wan, which in the glyphs may correspond to the suffix cluster $130.116,-w a-n$. One could consider a reading na.ka(h)-wa, "the mother/house/lineage is remembered", but I regard this as unlikely. 
The lady chosen to establish Pacal's descent line in the presence of the invoked "ancestors" represented by God N was seated on the side Pacal's on a day Caban, the day of the young Moon Goddess, a date coinciding with Full Moon and with the Vernal Equinox. ${ }^{16}$ On Princeton Vase No. 16 (Coe 1978:106) God N and the Moon Goddess are seated on both sides of one of the most intriguing resurrection motifs known from classic Maya iconography: The lower of a cartouche is occupied by the emerging upper body of a human being painted red-white, underneath crossed bands T153 (kaat, to cross over) and Cauac signs T528 (symbols of rain and the yearly round) placed in the upper part of the cartouche. A cross - eyed T272:546 deity mask on its top may symbolize the nightsun in the underworld. A flower-bearing "birth tree" rising from this mask reminds at the tree rising from Pacal's body on the lid of his sarcophagus in the crypt of the Temple of the Inscriptions. ${ }^{17}$ A fish placed at the lower left of the cartouche and the white-crested foam(?) on which God N. is seated indicate that the place of the scene the Jaguar God T1018a (= God GIII?) is seated on a Cauac monster throne, bearing on his back a spiral-eyed mask of the T272: 546 monster, the dying sun descending into the underworld. To the left of the central scene a second Cauac monster throne supports two other deities, Coe's Monkey-Man God holding a codex, and behind him a deity with a flower growing from his armpit the stalk of which is covered with numbers. A Moan Bird hovering above God N, watching the scene, could represent God L, the ruler of the underworld. The scene suggests that the aged God N, seated to the left of the cartouche, and the young Moon Goddess, leaning against the right side of the cartouche, are the deities most intimately connected with the resurrection process, the rebirth of the "sun", the deceased human lord. God $\mathrm{N}$ might give a command to the

10 Precisely 84 tropical years late, Naranjo Stela 23 (E1-F16) records the marriage of a Princess of Tikal, T1000a.168a:569, with Lord Fire-Squirrel, T122.765v:117, of Naranjo on the Vernal Equinox and Full Moon date 9.13.18.4.18, 8 Etz'nab 16 Uo, 710-Mar-19. The Spring Equinox was also the preferred time for contracting marriages in classical China of the Han Dynasty (Bodde 1975:245).

${ }^{17}$ A tree - or pole-raising ceremony seems to be an essential part of an ancient ritual of the Maya, connected in its modern aspects with the transfer of the cuch (burden) or "cargo", and performed to secure fertility and agricultural prosperity. Redfield (1936) has given an excellent description of the pole-raising part of the modern rite; additional elements were discussed recently by Pohl (1981). This important ritual should be seen on the background of the classic Maya "birth tree" tradition, discussed in Dütting (1981:198). 
human being in the cartouche as indicated by the elaborate speech scroll extending from his mouth. The Moon Goddess is looking away, as if her job, the actual rebirth, is already done.

The triadic sign that crowns the mask of the night - sun consists from left to right of the symbol T58[552], zac.taan, "white ashes", the ashes of the deceased, of the stingray spine T212 (kix), the symbol of bloodletting and human blood, and of the Spondylus shell T607a, the ear-ornament of God GI, ${ }^{18}$ all three of them being prerequisites of the resurrection process, the rebirth of the night-sun which is represented by grapheme T546 underneath. The three symbols can be linked with the gods of the "resurrection triad", the gods GI, GII and GIII of the Palenque triad, the "ashes" with God GIII (the descending sun/Evening Star and night-sun; Sun Temple iconography), the bloodletting instrument with God GII (the reborn sun-maize deity; Foliated Cross Temple iconography), and the shell T607a with God GI (Venus Morning Star; Cross Temple iconography).

The crucial life-giving function the Moon Goddess probably was throught to assume in the rebirth/resurrection of a deceased human lord after he passed the purgatory in the underworld seems to be subject of a text inscribed on a classic Maya bowl in the collection of the Bayly Museum, Charlottesville, Virginia (1980.6.4, No.1214): ${ }^{13}$

is Lintel 9 of Yaxchilan, the latest lintel carved in Bird-Jaguar's reign, prcsents Lord Bird-Jaguar with his successor in office, Shield-Jaguar II. They exchange large "cloth-staffs" on a day (9.16.17.6.12) 1 Eb "end of" Yaxkin, 768-Jun-16, close to the Summer Solstice. Fastened to BirdJaguar's elaborate necklace are a bar, five trophy heads and two Spondylus shells. This ornament relates the Spondylus shells to the sacrifice by beheading, a relationshop apparent also in attire and function of God GI, the sacrificer of the Water-lily Jaguar, the night-sun in the underworld. I wonder whether the Spondylus shell T607a could have the morphemic value haw-, in Yucatec 'a section of something divided; to lie face up; cease, end, finish", previously attributed by me to T606.

Most interesting are the many worked Spondyius shells and the red paint found in Burial 5 of Piedras Negras (W. R. Coe 1959: 124; Fig. 64), the triple burial of male (about 45 years old) and of two sacrificed(?) children. Spondylus shells and stingray spines were also among the offerings found in the rich tombs of Mounds $A$ and $B$ at Kaminaljuyu, Guatemala. "In the lap (of the principal skeleton 1 of Tomb BI, for instance) lay stingray spines and a Spondylus shell containing a jade head packed in cinnabar" (Kidder et al., 1946: 74, 145). In Burial 5 of Piedras Negras a jadeite pendant probably was placed in the mounth of the buried lord.

19 I am grateful to Hasso von Winning for bringing this text to my attention. For T595, f'ol, "increase, multiply; descendants", sce Dütting 1981: 190 . 
A $179: 509$, "the fainting lord $(179=58[533]=z a c . a h a u)$ has died (509)"

B 229.617a:126, ac?.hil.ah/ih, "it begins the resting"?

C $45.843 \mathrm{v}$, (in the realm of God N, in the underworld)

$\mathrm{D}, \mathrm{E} 62.77$ - 585aP?, hol.xik.be?, "end of the dangerous way"?

F 513:140, xoc/tzic..., "the honorable one"?

G 113.568, ta.lom?, "is at the place of piercing"?

H 501:139, nab..., "(to) the sea"

I 177.528.181, cub?.haab.uh?, "has descended the rain-bringing moon"?

J 561a:23.367, caan.na.zut?, "the heavenly (mother) returned"?

$\mathrm{K}$ 213inv.565a?, "the owner $(565 \mathrm{a}=t a h$ ?) of the sprouts (213)"

L 210.595, nak?.p'ol, "the womb (who gives birth) to the increase/ descendants".

Two graphemes, T568 in G and T595 in L, are placed into a quadrangle of 4 little circlets, the meaning of which is unknown.

In one of the strangest themes of the Maya Book of the Dead preserved in pottery scenes, the young Moon Goddess is sitting in the coils of a huge bearded serpent, the tail of which terminates in the body of God K. Out of the opened jaws of this serpent the Mam, the old ugly God $\mathrm{N}$ emerges, trying to fondle the lady's breast (see Vessels 9-12a in Robicsek-Hales 1981). These scenes are watched by bundled deities, on Vessel $12 \mathrm{a}$ by the bundled Pax God and the bundled God GI, perhaps some sort of "mummy bundles". Accompanied are these scenes by mythical CR dates (always with Tzolkin day Muluc) and a "birth" text, e.g. Vessel 12:

13 Muluc 18 Pax (in LC only 17 Pax possible) /

$740.181: 126$ ?, poc-ah.ih?, "washed [at birth] is the grandchild / descendant" / $1000 \mathrm{v}$, ahau?, "the lord", or mehen?, "the son"20/ 714.181 , p'ix/kah.uh, "awakened/remembered is the necklace"? / $110.758 \mathrm{v}$, chic.tz'ub?, "appeared has the child" / 58.762 , zac.balam-can/chan, "the resplendent jaguar-snake" / $1000[509] .60 \mathrm{~b} ?: 501$.

While I preferred previously a reading cux-, "come to life, be born", of the "fish in hand" grapheme T714 (Dütting 1980:126);

za This glyph could also be the female head T1000b, but I regard it as unlikely that the text refers to the birth of the goddess. 
I like to reserve this value now for the "shell" grapheme T606, in recent papers intrepreted by me as haw-, "lie face up". ${ }^{21}$

There were four Mams or Pauahtuns, according to the initial glyphs of the pottery standard glyph sequence the first deities encountered by the deceased in the underworld. In the remarkable scene on Vase No. 1 of the November Collection (Robicsek-Hales 1982) they occupy a lower level of the underworld than the four Bacabs, God N-type deities with Cauac markings on their bodies.

It seems that the four Mams were able to regain their youth through alcoholic intoxication, the intoxicant being administered rectally by means of an enema syringe (Furst and Coe 1977). According to Princeton Vase No. 11 (Coe 1978:76) the place of this ritual seems to be a cave-like Cauac monster palace in the interior of the earth where GI-type deities (T1030b-1011), termed Rain Beasts by Coe, play musical instruments (the same deities capture "fishes"/human embryos? for rebirth on Tikal Temple I Bones MT-51). Four Mams are present, each one with a female consort. The two in front become undressed by the ladies for the injection. Enema jars with syringes on top are placed in front of them. The two undressed Mams in the back may have been injected already. One of them is fanned by his consort, the other is looking into a mirror held by his mistress. ${ }^{22}$ A complete myth cycle concerned with the rejuvenation of the Mams was collected by Stresser-Péan (1952) from the Maya-speaking Huastecs of northern Veracruz. Mendelson (1967:406) has sketched this myth cycle as follows:

The Mamlabs, divinized ancestors, the servants of the great god of lightning. "drive the clouds over the earth in the guise of little men holding the lightn. ing machete or ax... The clouds seem to rush towards the mountains, ex-

${ }^{21} \mathrm{~T} 606=c u x$ is an old reading of Barthel and myself, later abandoned by both of us, by Barthel for T606 - et and T606:23 - et-al, "sign". In case T606 $=c u x$ is correct, one could interpret T606:23 as cux-(t)-al, "life" (Yuc/Mopan/Cholti/Chol), Cux-an, "living alive", or cux-nah, "be born" (know only from Chorti), depending on the value assigned to T23 (al or $n a / a n$ ).

22 Below this scene the repetition of the glyph compound T153.511 could denote kat.toh, "asking for rain". With respect to T511, toh, note Quiche (Edmonson) toh $=$ rainstorm; Mixe (Totontepec) too $=$ lluvia. With respect to T153, kat?, note Yucatec (Motul) kat - pedir, preguntar, inquirir; kaat = pasearse, andar cruzando; kaatal $=$ cosa que está atravesada. Chol (Aulie) $c^{\prime}$ ajtin = preguntar, pedir; $c_{A}^{\prime} t \wedge !$ - atravesado. Previously I followed Thompson $(1950: 108)$ in reading $T 552$ as kat. I accept now the reading tan/taan of the latter grapheme. An alternative reading of T153.511 could be kaat.toh, "it crosses over (from old age to regained youth) the true/ straight/legitimate one". 
plained by the sexual desire of the godlines who meet with their females in the mountain caves. The females are frog goddesses whose call summont the rain of the warm season. The caves are then thought of as the scenes of orgies and nightly parties with dances and music and alcohol. But the Huas. tecs envisage love as... a kind of passing excess which weakens the lover in his physical as well as magical strength. Thus the godlings come out with the waters from the mountain sources and float towards the eastern ocean. They are then thought of as Ocel: degenerate, old, decrepit gods... They now symbolize vegetation and often rest on certain kinds of plants whose leaves retain rain-water, They are also masters of jungle animals, especially the dangerous ones... They no longer bring fertilizing rains but a variety of diseases.

But their drunkeness carries within itself its own regeneration. When floating in the sea they will swoon in a deep sleep of drunkeness like a momentary death... From this they will find the strength to start again as young gods or lightning and thunder".

The Mams play an important role in the religious beliefs of several lowland Maya groups. Thompson (1930:57), who investigated the worship of the Mams (also called Huitz-Hok. "mountain-valley") by the Mopan Maya of Belize, wrote:

"The Mams are gods of the mountains, of the plains, of thunder and lightning, and, by extension of the rain. They are too, gods of hunting and fishing and agriculture, although in this branch they are not the sole pa. trons". And on p. 62: "The Mayas of San Antonio recognize the Chacs and the Mams as being one and. the same, but the blending of the twc sets of deities is not complete".

According to the Huastec myth cycle the Mams are gods of thunder and lightning, of the rains, only in their rejuvenated, dwarf-like(?) form. Among the Human figures painted on the hidden walls of the caves of Naj Tunich, some of them in sexual excitement, we recognize also dwarfs, possibly the rejuvenated Mams. Text $I V j$ of Naj Tunich (near Poptun, Guatemala, in the Mopan area; Stuart 1981) may address the rejuvenated Mam as "lord of rain":

A1 539:74.502:178, balan-ahau.mah.ma-l(a), "the hidden lord, the master, passes by"?

A2 $561: 23$, caan.(na), "the heavenly one"

A3 229.528v, ac-tun, "(in the) cave"

A4 ?.168b:528, ...ahauhaab, "the... lord of rain"

A5 758:110, tz'ub.chic?, "the child/youth which appeared".

The term tz'ub, "child/youth", one of the possible translations of main sign T758, the head of a Spotted Agouti or Pisote, is taken from Mopan Note furthermore Yucatec (Motul): ac uinic = enano; actun = cueva; mal = pasar por algún lugar. 
The Popoluca of the Mixe-Zoquean language group have the belief in dwarf guardians of the animals, termed Chanekos, who live in huge mountain caves where they tend game, particularly deer, as men keep cattle (Foster 1945:181).

The rejuvenation of the Mam may play some important role in the ancestor worship of the Maya. It certainly is a paradigm of the human quest for immortality, just as the daily death and rebirth of the Sun provided the cosmic metaphor for the death and supposed resuscitation of a Maya lord.

\section{A Winter Solstice Record}

Like other ancient societies the classic Maya recognized the solstices and equinoxes as corner-points of their seasonal year. While searching for dates in the Mayan inscriptions that correspond to the solstices the inscription of Ikxun Stela 2 came to my attention, a drawing which (Fig. 6) was published by Ian Graham (1980). The main subject of this text seems to be the Winter Solstice, which separates a previous period of a gradual shortening of days from a subsequent period of a gradual renewal of light.

The text of Ixkun Stela 2 starts with an IS date (A1-A11), 9.17.9.0.13, 3 Ben [6] Kayab, 779-Dec-17 (moon age $5^{d}$ ), 1 day before the actual Winter Solstice (Dec 18 in Julian reckoning, when the sun is in the ecliptic longitude of $270^{\circ}$. The Supplementary Series, in A6-B10 inserted between the Tzolkin position 3 Ben (B5) and the Haab position 6 Kayab (A11), first refers to the 4th Lord of the Night (glyphs G4/F), continues then with three unusual glyphs (A7-A8), 245?.586:178? / 1.122:563a, u.kak.(zi), "his/her fire" / V?.?:? (compare the IS date of Itzán St.17, chapt. II), and finishes with the Lunar Count glyphs (B8-B10), 5D (age of current moon $5^{\mathrm{d}}$, in accordance with the moon age predicted by the 584,285 correlation), 3C (three lunations completed in cycle of six), X3, B A10 (supposed length of current lunation $30^{4}$ ). The IS date is followed by the event glyphs (B11,A12), 122:head.? / 653[568]:82.?, hulil..., "spearing", and then by a u.cab phrase that usually introduces a human lord (B12,C1): 204.526:246, u.cab.mayih?, "his offering? to the earth", or "his travelling over the land" / VIII.skull, "8 Skull" (name of local lord?). One could ask whether "8 Skull" is a reference to the deceased, to the sun in the underworld, to the speared victim in the darkness of the Winter Solstice, this because 
the initial part of the following, much eroded glyp D1 may be $546: 23$, interpreted by me as $h o(k)$.kin.na, "emerging of the sun from its house".

The text continues with a DN introducing glyph (C2), 1.504?.544?:12, with the head of the God of the number 5, the aged God N (D2), and with a seated "fire-bearer", a scated figure bearing the "fire" glyph 122:563a with a tumpline on the back (C3). A DN of 1 day (D3), I.561 (tilted):544:526, literally referring to a single sunrise, leads to the implied date of the Winter Solstice, (9.17.9.0.14, 4 Ix 7 Kayab), 779-Dec-18, to which the fire is brought across from the previous day. This date is followed by three event glyphs (C4-C5) that may refer to the victorious sun, to the sun revived after passing the longest night:

$190: ? .25$ ?:683a, bat...ca(y)?.kal, "the fighting finishes? the enclosure (of)", or "victory of the enclosed one" $606: 23$, cux-an?, "the revived one" / 599 ? - 116.561:23, tan?.(n).caan.( na), "in the center of heaven". ${ }^{24}$

The insertion of the God $\mathrm{N}$ glyph and of the fire-bearer glyph before the hatzcab (dawn) glyph emphasizes the emerging of the sun (the fire-bearer?) from the realm of God $\mathrm{N}$, from the underworld. The axe grapheme T190, bat/baat, usually refers to a "fighting" (bateel in Yucatec). The glyph could refer to a ritual of violence, to a mock battle at the Winter Solstice, comparable to those reported from the Winter Solstice ceremonies of the Hopi and other Pueblo Indians of the Northamerican Southwest, performed to strengthen the sun's journey across the sky (Ortiz 1972:152).

The next glyph (D5) cannot be recognized, but then the text continues with a second u.cab phrase $(\mathrm{C} 6, \mathrm{D} 6)$ :

204.526:246, u.cab.mayih?, "his offering to the earth"? / $687 \mathrm{a} .177: 12.653[568]$, (name/title of divine lord).

The grapheme T568 pierced by an arrow, T653[568], hul, "to spear", is known otherwise only from the Venus Tables of the Codex Dres-

23 The published photograph of Ixkun Stela 2 does not allow to clarify all details of this glyph. The element beneath the axe could be T511 (toh), the superfix of T683a could be T24 (il) instead of T25 (cah/cay/ca).

24 Alternative readings could be T599, $t z^{\prime} u$, "center" (Yuc), and T116, kin, "sun, day". 
den. In D6 the ah.hul (12.653-568), "the one who shoots/spears", the hunter (of celestial origin?), probably is said to "descend" (T177 $=c u b / e m ?$ ?). Actually Venus was Morning Star in Scorpious on 779. Dec-18, $60^{4}$ after Inf. Conj. of 779-Oct-19.

The readable text ends with a DN $2.10=50^{\text {d }}$ that leads to the date (9.17.9.3.4) [2 Kan] 12 Pop (Tzolkin position written $1 \mathrm{Akbal}$ according to previous day 1 Akbal 11 Pop), followed by the event glyphs 122:head:18 / 87:281:elbow (C7-C9). Most likely the two day sequence 9.17.9.3.3/ 9.17.9.3.4, 780-Feb-5/6 (moon ages 25\%/ $\left.26^{\mathrm{d}}\right)$, is meant. The significance of this second two day sequence, $50^{4}$ after the first of the Winter Solstice, remains to be elucidated. ${ }^{25}$

\section{REFERENCES}

Benson, Elizabeth

1976 "Ritual Cloth and Palenque Kings", in The Art, Iconography and Dynastic History of Palenque, Part III (ed. by Merle Greene Robertson), pp. 45-48, Robert Louis Stevenson School, Pebble Beach (Calif.).

Berlin, Heinrich

1965 "The Inscription of the Temple of the Cross at Palenque", BODNE, DERK American Antiquity 30, 330-342, Salt Lake City.

1975 Festivals in Classical China, New Year and Other Annual Observances During the Han Dynasty 206 B.C. - A.D. 220,

Coe, Michaes. D. Princeton University Press, Princeton, N.J.

1973 The Maya Scribe and His World, The Grolier Club, New York.

1978 Lords of the Underworld, The Art Museum, Princeton Uni-

Coe, Wrilam R. versity, Princeton.

1959 Piedras Negras Archaeology: Artifacts, Caches and Burials, DítTing, Dieter The University Museum, Philadelphia.

1965 "Das Knoten-Graphem bei den Maya", Zeitschrifth für Ethnologie, 90, 66-103, Braunschweig.

1976 "The Great Goddess in Classic Maya Religious Belief", Zeitschrift für Ethnologie, 101, 41-146, Braunschweig.

1978 "Bats" in the Usumacinta-Valley, Remarks on the Inscrip-

25. The distance of $50^{4}$ corresponds about to the distance between the classical Chinesse (Han) festivals of Winter Solstice and Spring's Beginning (Bodde 1975: 189). The "fire" glyphs in the Winter Solstice text of Ixkun Stela 2 actually remind at the "yang ether" of the Chinese yin-yang cosmology, the element "fire" which in Chinese thought becomes dominant at the Winter Solstice (Bodde 1975: 175), this in contrast to the "yin ether". the element "water" which becomes dominant at the Summer Solstice. 
tions of Bonampak and Neighboring Sites in Chiapas, Mexico", Zeitschrift für Ethnologie, 103, 1-56, Braunschweig.

1978a "Birth, Inauguration and Death in the Inscriptions of $\mathrm{Pa}$ lenque, Chiapas, Mexico", in Tercera Mesa Redonda de Palenque, Vol. IV (ed. by Merle Greene Robertson and Donnan C. Jeffers), pp. 183-214, Herald Printers, Monterey (Calif.).

1979 "On the Hieroglyphic Inscriptions of Three Monuments from Piedras Negras, Guatemala", Zeitschrift für Ethnologie, 104, 17-63, Braunschweig.

1980 "Aspects of Classic Maya Religion and World View", Tribus, 29, 106-167, Linden-Museum, Stuttgart.

$1980 \mathrm{a}$ "On the Context-dependent Use of $\mathrm{Bi}-$ and Polyvalent Graphemes in Mayan Hieroglyphic Writing", in The Fourth Palenque Round Table, 1980, Vol. 6, ed. Elizabeth P. Benson, Univ, of Texas Press, Austin, forthcoming.

1981 "Life and Death in Mayan Hieroglyphic Inscriptions", Z t.tschrift für Ethnologie, 106, 185-228, Berlin.

1984 "Venus, the Moon, and the Gods of the Palenque Triad", Zeitschrift für Ethnologie, 109, 7-74, Berlin.

n.d. "On the Astronomical Background of Mayan Historical Events", Foster, Georce M.

Forthcoming in Fifth Palenque Round Table, 1983, Vol. 7.

1945 Sierra Popoluca Folklore and Beliefs, University of California Publications in American Archaeology and Ethnology, Vol. 42, No. 2, Berkeley (Calif.).

Ferst, Peter T., and Michael D. Coe

1977 "Ritual Enemas", Natural History, 86, No. 3, 88-91.

Goldstine, Herman H.

1973 New and Full Moons 1001 B.C. to A.D. 1651, Memoirs of the

GRAHAM, IAN American Philosophical Society, Vol. 94, Philadelphia.

1980 Corpus of Maya Hieroglyphic Inscriptions, Vol, 2, Part 3, Peabody Museum, Harvard Univ., Cambridge (Mass.).

Kidere, Alfred V., J. D. Jennings and E. M. Shook

1946 Excavations at Kaminaljuyu, Guatemala, Carnegie Institution

LAMB, WELDON of Washington, Publ. 561, Washington, D.C.

n,d. Paper presented at Fifth Palenque Round Table Conference, June, 12-18, 1983, Palenque, Chiapas, México.

Macleod, Barbara

n.d. An Epigrapher's Annotated Index to Cholan and Yucatecan Verb Morphology.

Mayer, Karl Herbert

1980 Maya Monuments: Sculptures of Unknown Provenance in the United States, Acoma Books, Ramona, Calif.

Mendelson, E. Michael.

1967 "Ritual and Mythology", in Handbook of Middle American Indians, Social Anthropology (Vol. 6), pp. 392-415, University of Texas Press, Austin.

Nevgebauer, Paul Victor

1938 Tafeln zur Berechnung der jährlichen Auf-und Untergänge der Planeten, Astronomische Nachrichten, Bd., 264, No. 6331, Kiel.

von OpPolzer, Theodor

1887 Canon der Finsternisse, Denkschriften der Kaiserlichen Aka- 
demie der Wissenschaften, Mathematisch- Naturwissenschaftliche Klasse, Vol. 52, Wien.

Ortiz, AlFonso

1972 "Ritual Drama and the Pueblo World View", in New Perspectives on the Pueblos, ed. Alfonso Ortiz, pp. 135-161, Univ.

PoHL, MARY of New Mexico Press, Albuquerque.

1981 "Ritual Continuity and Transformation in Mesoamerica: Reconstructing the Ancient Maya Cuch Ritual", American Antiquity, 46, 513-529, Washington, D.C.

ProskourLakofF, TATLANA

1960 "Historical Implications of a Pattern of Dates at Piedras Negras, Guatemala", in American Antiquity, 25, 454-475, Salt Lake City.

REDFIELD, ROBERT

1936 "The Coati and the Ceiba", Maya Research III, 231-243, Baltimore.

Robicsek, Francis, and Donald M. Hales

1981 The Maya Book of the Dead. The Ceramic Codex, University of Oklahoma Press, Norman.

1982 Maya Ceramic Vases from the Late Classic Period, The November Collection of Maya Ceramics, Charlotte (North Carolina).

Ruz LHULLLIER, Alberto

1952 "Exploraciones en Palenque: 1950", Anales del Instituto NaSCHELE, LiNDA cional de Antropologia e Historia, Vol. 5, pp. 25-45, México.

1978 "Genealogical Documentation on the Tri-figure Panels at Palenque", in Tercera Mesa Redonda de Palenque, Vol. IV (ed. by Merle Greene Robertson and Donnan C. Jeffers), pp. 41-69, Herald Printers, Monterey (Calif.).

1982 Maya Glyphs. The Verbs, Univ. of Texas Press, Austin.

1982a Notebook for the Maya Hieroglyphic Writing Workshop at Texas, Institut of Latin American Studies, Univ. of Texas at Austin, Austin.

Schele, Linda, and Peter Mathews

1979 The Bodega of Palenque, Chiapas, Mexico, Dumbarton Oaks, Trustees for Harvard University, Washington, D.C.

Schele, Linda, and Jeffrey H. Mitler

1983 The Mirror, the Rabbit, and the Bundle: "Accession" Expressions from the Classic Maya Inscriptions, Dumbarton Oaks Research Library, Studies in Pre-Colombian Art \& Archaeology No. 25, Washington, D.C.

SCHRAM, ROBExT

1908 Kalendariographische und Chronologische Tafeln, J. C. Hinrichs, Leipzig.

Stresser,-PéAn, GuY

1952 "Montagnes calcaires et sources vauclusiennes dans la religion des Indiens Huastèques de la région de Tampico", Revue de

Stunat, Georoe E. PHistoire des Religions, 141, 84-90, Paris.

1981 "Maya Art Treasures Discovered in Cave", National Geographic Magazine, 160, No. 2, 220-235, Washington, D.C.

Thомpson, J. Eric S.

1930 Ethnology of the Mayas of Southern and Central British Hon- 
duras, Field Museum of Natural History, Anthropological Series, Vol. 17, No. 2, Chicago.

1935 "Maya Chronology: The Correlation Question", Carnegie Instituition of Washington, Publ. 456 Contributions to American Archaeology, No. 14, Washington, D.C.

1950 Maya Hieroglyphic Writing, Carnegie Institution of Washington, Publ. 589, Washington, D.C.

1962 A Catalog of Maya Hieroglyphs, University of Oklahoma Press, Norman.

1970 Maya History and Religion, University of Oklahoma Press, Norman.

1972 A Commentary on the Dresden Codex, Memoirs American Philosophical Society, Vol. 93, Philadelphia.

Tuckerman, Bryan

1964 Planetary, Lunar, and Solar Positions, A.D. 2 to A.D. 1649 at Five-Day and Ten-Day Intervals, Memoirs American Philosophical Society, Vol. 59, Philadelphia. 


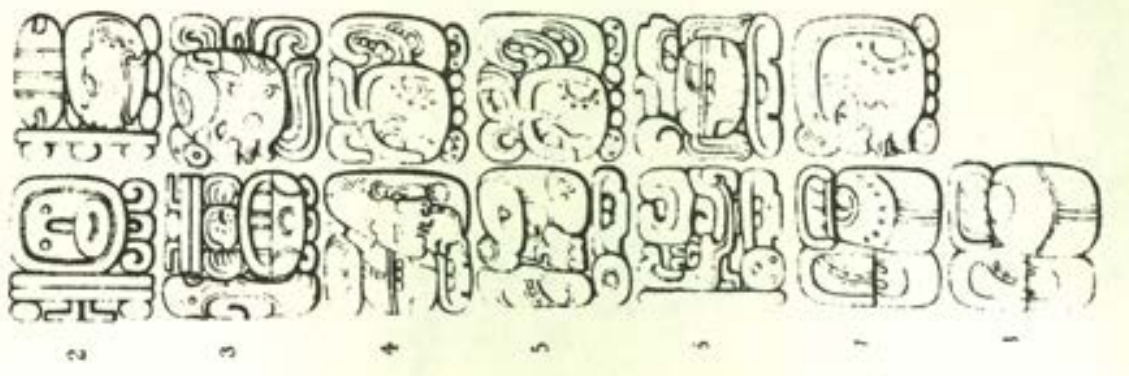

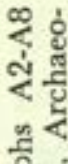

点贻

สำ

눈

बैं

हैं

है

․․․․․

․․․

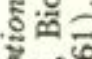

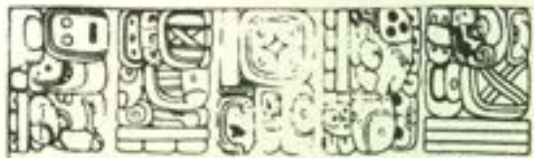

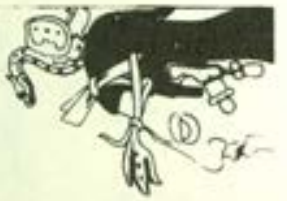

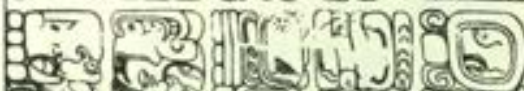

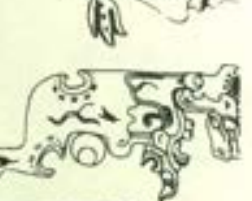

$\frac{2}{3}$

3

है

$\checkmark$ 西

过紧?

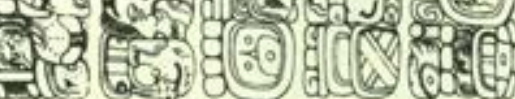

(6)

4 .

dics) कु.



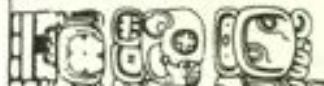

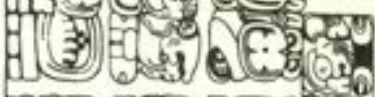




है

की

$N<\bar{\circ}$

过总总

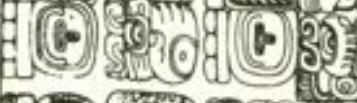

(a) (C)

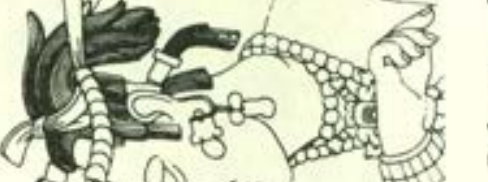

ปั้

mi

离


c a TE



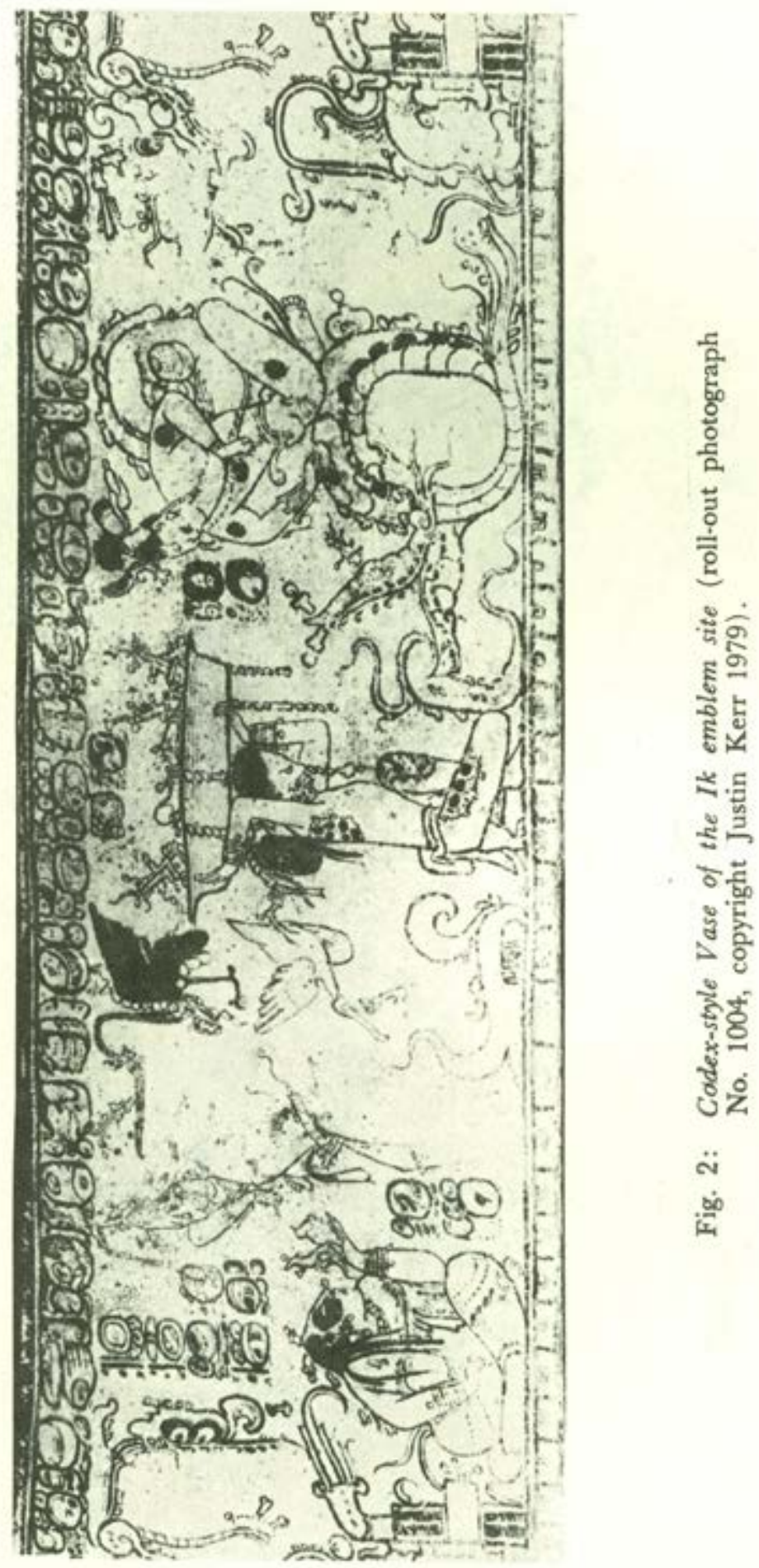




\section{(3) \\ (9)}

苌

产的

บั

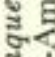

क्ष

बैं ⿷匚

¿े

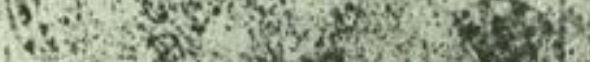

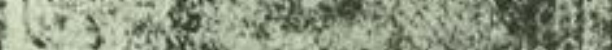

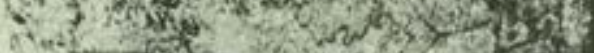

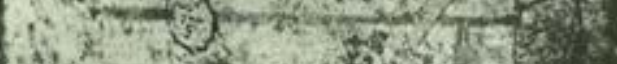

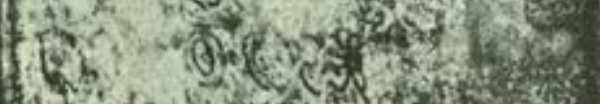

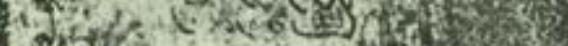

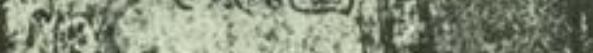

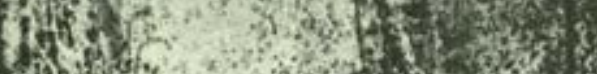

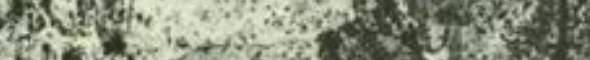

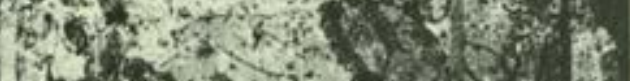

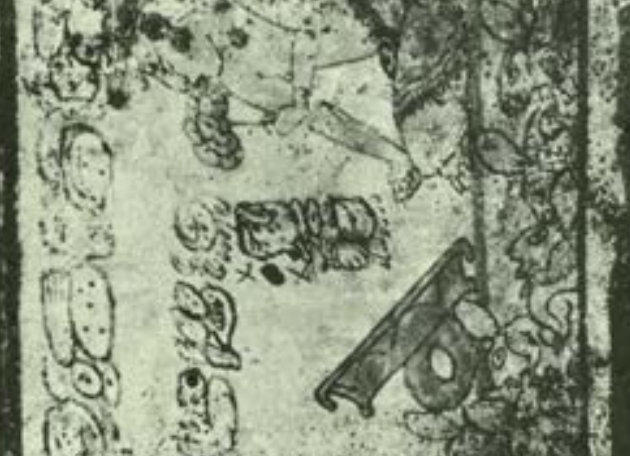

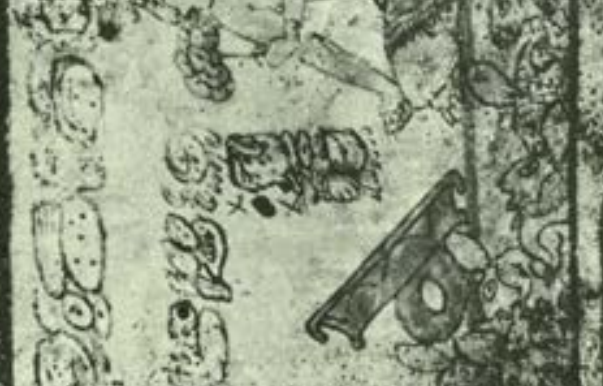

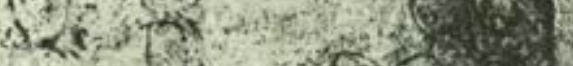

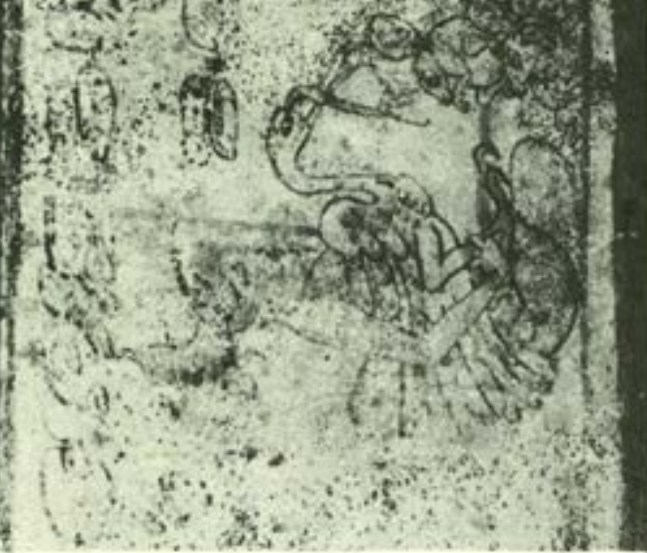

ฉ்

है. 땡

$+\frac{6}{9}$



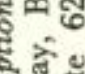

焉

咅



की:

낙



चुँ्ठ

- क

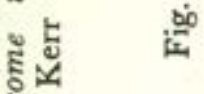

든

ลิํำ

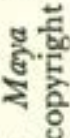

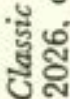

$\ddot{+}$

章 


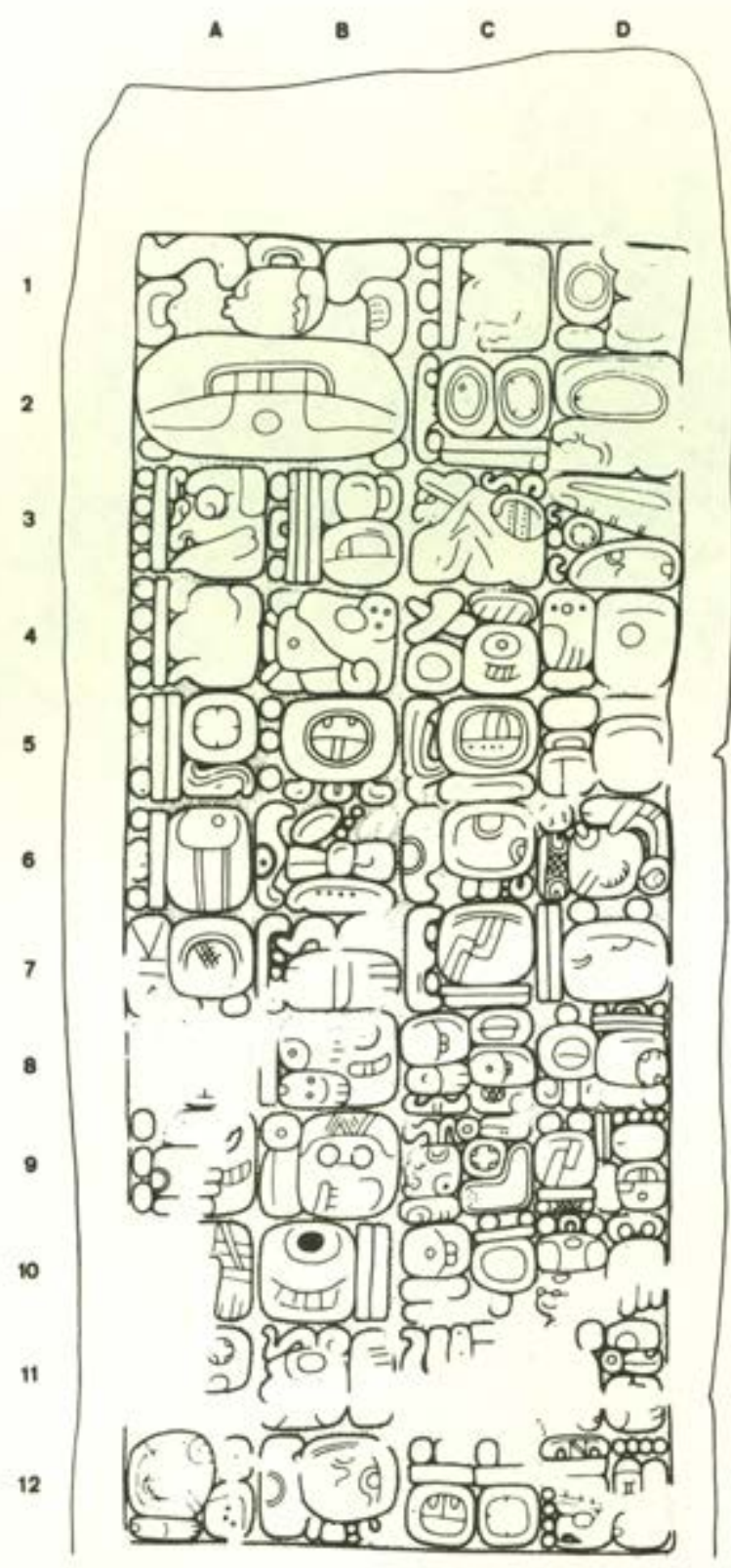

Fig. 6: Ixkun Stela 2, inscription (drawing by Ian Graham). 